\title{
Hungarian cases before ICSID tribunals: the Hungarian experience with investment arbitration
}

\author{
Csongor István NagY*
}

\begin{abstract}
The paper presents, in an analytical manner, Hungary's legal experiences with international investment arbitration, giving an in-depth overview of the country's ICSID cases and their background. Investment disputes are notoriously complex and have several political, economic and regulatory aspects. The purpose of the paper is to present the Hungarian investment disputes in the context of their local background and the national regulatory environment.
\end{abstract}

Keywords: Bilateral investment treaties, EU law, investment protection, investor-state arbitration, expropriation, fair and equitable treatment

\section{INTRODUCTION}

Central and Eastern Europe is considered to be the litmus paper of investment arbitration in Europe. Central European countries are popular targets of investment disputes: the overwhelming majority of the cases against EU Member States are proceedings launched against countries from the region. Arguably, these countries may be characterized by intensive intervention in the market, the state's strong regulatory role and the entrenched social status of public services, which, by their nature, may interfere with the economic interests of foreign investors. In these procedures, arbitral tribunals judge measures that are part of the core of national regulatory sovereignty, such as national privatizations, protection of public health, regulation of prices and curbing of monopolies, and the exercise of contractual rights. ${ }^{1}$ Hungarian investment arbitration cases are no exception to these experiences.

This paper endeavors to present, in an analytical manner, the legal aspects of the Hungarian experience with international investment arbitration, providing an in-depth overview of the country's ICSID cases and their background. Investment disputes are notoriously complex and carry several political, economic and regulatory aspects, this is why this paper depicts the selected Hungarian investment disputes in the context of their local background and national regulatory environment.

* Csongor István Nagy, LL.M., Ph.D., S.J.D, dr. juris is professor of law and head of the Department of Private International Law at the University of Szeged and research chair and the head of the Federal Markets 'Momentum' Research Group of the Hungarian Academy of Sciences, and an attorney-at-law admitted to the Budapest Bar. He is recurrent visiting professor at the Central European University (Budapest/New York), the Riga Graduate School of Law (Latvia) and the Sapientia University of Transylvania (Romania). This research was supported by the project nr. EFOP-3.6.2-16-2017-00007, titled Aspects on the development of intelligent, sustainable and inclusive society: social, technological, innovation networks in employment and digital economy. The project has been supported by the European Union, co-financed by the European Social Fund and the budget of Hungary. When writing this paper, the author was senior research fellow with the International Law Research Program of the Center for International Governance Innovation and gratefully acknowledges its support. Email: csongor.nagy@gmail.com

1 On the Central European perspectives see Nagy (2017) 309-32. 


\section{BUDAPEST AIRPORT: COMPENSATION FOR ILLEGAL EXPROPRIATION}

The fact pattern of ADC Affiliate Limited and ADC \& ADMC Management Limited $v$. Republic of Hungary ${ }^{2}$ centered around a blatant expropriation: Hungary, through a legislative act, eliminated the claimants' right to operate two terminals of the Airport of Budapest. This matter is one of the very rare cases where the tribunal pronounced the taking unlawful and, instead of the 'market value plus interest' test, it applied the in integrum restitutio standard. ${ }^{3}$

In 1995, the claimants, two Cypriot enterprises, entered into a contract with the Hungarian Air Traffic and Airport Administration (ATAA, a Hungarian state agency), whereby they agreed to renovate Terminal $2 \mathrm{~A}$ and to construct Terminal $2 \mathrm{~B}$ of the BudapestFerihegy International Airport (currently: 'Budapest Ferenc Liszt International Airport') and to participate in their operation. They finished the construction and operation works in 1998 and operated the two terminals until the end of 2001, when their rights related to operation were abolished through a legislative act. The Air Traffic Act (Act XCVII of 1995) was amended late 2001 (through Act CIX of 2001) and the minister of transport and water management issued a decree (Decree 45 of 2001) under the authority of the new provisions of the amended act, Section 1(5) of which appointed a public limited company, Budapest Ferihegy Nemzetközi Repülőtér Rt. as the Airport's exclusive operator.

The tribunal found the expropriation unlawful because Hungary failed to name a legitimate (and credible) public interest goal, the taking was discriminatory and due process was not observed, as well as just compensation was not provided. ${ }^{4}$

The illegality of the expropriation changed the standard on the calculation of quantum. Under the applicable BIT, in case of lawful expropriation, the compensation equaled the market value at the time of expropriation plus interests. ${ }^{5}$ However, since the taking was considered to be unlawful, this standard could not be applied. Although there was 'general authority for the view that a BIT can be considered as a lex specialis whose provisions will prevail over rules of customary international law', as the BIT concluded by Cyprus and Hungary contained no provision as to damages to be paid in case of unlawful expropriation, ${ }^{6}$ the tribunal (in the absence of any lex specialis) applied 'the default standard contained in customary international law', ${ }^{7}$ which was mainly based on Chorzów Factory (Claim for Indemnity) (Merits), Germany v. Poland, P.C.I.J. Series A., No. 17 (1928). ${ }^{8}$ According to this, the injured party is entitled to in integrum restitutio - the plight that existed prior to the illegal act (expropriation) has to be restored; that is, the injured party has to be brought into the situation that would have existed should the illegal act has not occurred.

2 ICSID Case No. ARB/03/16.

${ }^{3}$ On the conditions of lawful taking see Víg and Doklestic (2015). On compensation theories in international investment protection law see Víg and Gajinov (2016) 447-61.

${ }_{4}$ Award (2 October 2006), paras 426-44.

5 Para 482. Article 4(2) of the Cypriot-Hungarian BIT provided that '[ $\mathrm{t}] \mathrm{he}$ amount of compensation must correspond to the market value of the expropriated investments at the moment of the expropriation.'

6 Para 481.

7 Para 483.

8 Para 480. \& 499. 
Reparation must, as far as possible, wipe out all the consequences of the illegal act and re-establish the situation which would, in all probability, have existed if that act had not been committed. ${ }^{9}$

Restitution in kind, or, if this is not possible, payment of a sum corresponding to the value which a restitution in kind would bear; the award, if need be, of damages for loss sustained which would not be covered by restitution in kind or payment in place of it. ${ }^{10}$

Hence, the relevant point of time (as regards the market value) was not the moment of expropriation but the time when the award was rendered. Hungary had to compensate the claimants for 'all unpaid dividends and management fees from the date of expropriation until the date of the award'. ${ }^{11}$ As the value of the Airport (more precisely that of the right to operate it) increased considerably, the difference in the calculation standard entailed a significantly higher quantum.

\section{UNIVERSAL SERVICE IN ELECTRONIC COMMUNICATIONS}

In Telenor Mobile Communications A.S. v. the Republic of Hungary, ${ }^{12}$ the claimant claimed damages for expropriation and failure to accord fair and equitable treatment and protection for its investment. ${ }^{13}$ Telenor was the sole owner of Pannon (one of the three mobile service providers in Hungary at that time), whereas $75 \%$ of the shares in the claimant were owned by the state of Norway). ${ }^{14}$

Pannon obtained a concession in 1993 (for which it paid certain fees: concession fee, frequency allocation fee, frequency usage fee). ${ }^{15}$ Afterwards, influenced by EU electronic communications legislation (although at that time Hungary was not part of the EU yet), Hungary introduced the concept of universal service in the regulatory regime of the telecommunications market: consumers were afforded the right to a particular set of electronic communications services, irrespective of geographic location and economic considerations. ${ }^{16}$ The provision of universal service was limited to fixed-line operators; Hungary entrusted the fixed-line operators with the provision of the universal service and established a funding mechanism to compensate the universal service providers for the unrecovered costs incurred: it created the Universal Telecommunications Support Fund (ETTA) and obliged all, mobile and fixed telecommunications service providers to contribute a portion of their revenue to the fund. Likewise, Hungary introduced regulated prices for mobile service providers with significant market power (SMP), establishing regulated prices regarding interconnection (call termination) services. ${ }^{17}$ Furthermore, the

9 Permanent Court of International Justice, Factory at Chorzów, Judgment No. 13, 13 September 1928, Series A, No. 17, p. 47.

10 Permanent Court of International Justice, Factory at Chorzów, Judgment No. 13, 13 September 1928, Series A, No. 17, p. 47.

11 Para 518.

12 ICSID Case No. ARB/04/15 (September 13, 2006).

13 Award (13 September 2006), para 17.

14 Para 16.

15 Para 29.

16 As to the regulatory concept of universal service see Nagy (2013) 1731-56.

17 Paras 23-24. 
Hungarian Competition Office imposed a fine on Pannon for abuse of its dominant position (the review of the HCO's decision was pending when the statement of claim was filed).

Telenor based its case on four grounds: first, since mobile service providers could not be appointed as universal service providers, Pannon was deprived of business opportunities; second, it had to contribute to the ETTA, although the fund was distributed among fixedline universal service providers only; third, it was designated as a service provider with SMP and, hence, was subjected to regulated prices; fourth, it was imposed a competition fine. ${ }^{18}$

The tribunal found that no expropriation occurred: ${ }^{19}$ it concluded 'that Telenor has failed to make out a prima facie case of expropriation' and, hence, it had no jurisdiction for claims for expropriation. ${ }^{20}$

The tribunal held that although the concept of expropriation encompasses also indirect or creeping nationalization, ${ }^{21}$ 'the mere exercise by government of regulatory powers that create impediments to business or entail the payment of taxes or other levies does not in itself constitute expropriation.'

64. (...) Any investor entering into a concession agreement must be aware that investment involves risks and that in some degree the investor's activities are likely to be regulated and payments made for which the investor will not receive compensating advantages. These are all part of the price the investor has to pay for securing the concession. Similarly, unreasonable behaviour on the part of officials and breaches of contract, even if serious, do not by themselves constitute acts of expropriation. The conduct complained of must be such as to have a major adverse impact on the economic value of the investment.

65. There has been a substantial volume of case law, both under the Washington Convention and in general public international law, as to the magnitude of the interference with the investor's property or economic rights necessary to constitute expropriation. Though different tribunals have formulated the test in different ways, they are all agreed that the interference with the investor's rights must be such as substantially to deprive the investor of the economic value, use or enjoyment of its investment.

(...)

66. There have also been arbitral awards suggesting that deprivation of a substantial or significant part of the economic value of the investment may suffice to constitute expropriation. (...) However, these suggestions have typically been made in cases where the question of partial deprivation did not arise on the facts, and were no doubt designed to avoid excluding the possibility that partial deprivation might in an appropriate case constitute expropriation. (...)

67. The Tribunal considers that, in the present case at least, the investment must be viewed as a whole and that the test the Tribunal has to apply is whether, viewed as a whole, the investment has suffered substantial erosion of value.

18 Para 35.

19 Para 79.

20 Para 80.

21 Para 63. 
Specifically as to the ETTA and the contribution to the universal service fund, the tribunal established that these were "similar to measures introduced in other jurisdictions, all mobile service providers were excluded, not only the Pannon, and the contribution was not discriminatory, applied to all service providers'. ${ }^{22}$

Telenor's claims concerning fair and equitable treatment wrecked on issues of jurisdiction. Namely, the applicable BIT's dispute settlement clause subjected only expropriation claims to the tribunal's jurisdiction, while complaints as to fair and equitable treatment were not covered. The claimant argued that the tribunal should still have jurisdiction, due to the BIT's MFN clause: if Hungary stipulated the ICSID in any of its BITs also as to fair and equitable treatment cases, this extended jurisdiction shall be applicable also to investors from Norway. The tribunal rejected this interpretation of the relevant BIT and established that it had no jurisdiction to adjudicate the claim as to fair and equitable treatment. ${ }^{23}$

\section{REJECTION TO RENEW THE NATION-WIDE RADIO FREQUENCIES}

In Accession Mezzanine Capital L.P. and Danubius Kereskedöház Vagyonkezelö Zrt. v. Hungary ${ }^{24}$ and in Emmis International Holding, B.V., Emmis Radio Operating, B.V., and MEM Magyar Electronic Media Kereskedelmi és Szolgáltató Kft. v. Hungary, ${ }^{25}$ the legal dispute centered around Hungary's rejection to renew nationwide radio-broadcasting FM frequencies. The cases concerned Hungary's most popular radio stations: Danubius radio was shut down after 23 years of operation, whereas Sláger radio had a history of 11 years when its frequency license expired.

In Accession Mezzanine Capital L.P. and Danubius Kereskedöház Vagyonkezelö Zrt. v. Hungary, the two claimants (Mezzanine, a company organized under the laws of Bermuda and DSHV, a company organized and existing under the laws of Hungary) alleged that Hungary unlawfully expropriated - without compensation and without complying with other standards of treatment (set forth in the applicable BIT, customary international law and applicable law) - the claimants' investments in and related to Danubius Rádió Müsorszolgáltató Zrt. (Danubius Radio) and its operating activities.

Danubius Radio was a former licensee of one of the two nationwide FM radiobroadcasting frequencies in Hungary; first it obtained the frequency license in 1997 for a period of seven years, after participating in an international call for tender of the licenses; in 2004 the license was renewed for a period of additional five years. In 2009, Hungary's National Radio and Television Broadcasting Board published a call for tender for the issuance of frequency licenses; Danubius Radio's application was declared unsuccessful and it was not awarded a new frequency license. ${ }^{26}$ Claimants contended that the expropriation and inappropriate treatment resulted from Hungary's decision to carry out a tender procedure which replaced Danubius Radio with another licensee, notwithstanding the fact that Danubius Radio had successfully operated the radio-broadcasting frequency concerned for more than twelve years. ${ }^{27}$

22 Para 78.

23 Paras 91-95, 97 and 101.

24 ICSID Case No. ARB/12/3.

25 ICSID Case No. ARB/12/2.

26 Decision on Respondent's objection under Arbitration Rule 41(5), para 31.

27 Decision on Respondent's objection under Arbitration Rule 41(5), para 30. 
Since the claimants' case related to alleged expropriation appeared to be particularly weak, it was crucial for the claimants to have Hungary's conduct assessed under nonexpropriation treatment standards (such as fair and equitable treatment, prohibition of unreasonable and discriminatory measures). ${ }^{28}$ However, this raised serious issues of jurisdiction. Although the applicable BIT did contain provisions which could have been relied upon for this purpose (i.e., Article 3 contained 'National Treatment and MostFavoured-Nation Provisions', while Article 11 provided that '[i]f the provisions of law of either Contracting Party or obligations under international law existing at present or established hereafter between the Contracting Parties (...) contain rules (...) entitling investments by investors of the other Contracting Party to a treatment more favorable than is provided for by the (...) [BIT]', such rules prevailed to the extent they were more favorable), Article 8, referring exclusively to Article 6 of the BIT, confined the jurisdiction of the ICSID to expropriation claims.

To bring also non-expropriation claims into the ambit of the legal dispute, the claimants argued that, notwithstanding the BIT's dispute settlement clause, as the ICSID Convention mandates the tribunal to apply also international law, the tribunal had the power to adjudicate all claims emerging from international law as such. Notably, the issue of applicable law is governed by Article 42 of the ICSID Convention, which, in turn, in the absence of party choice, provides for the application of the law of the host state 'and such rules of international law as may be applicable'.

The tribunal held that albeit the interpretation and application of the BIT were, indeed, governed by international law and the concept of expropriation could not be interpreted 'without considering customary and general principles of international law, as well as any other sources of international law in this area' ${ }^{29}$ there is no basis 'to expand the tribunal's jurisdiction beyond expropriation and attendant rules of international law'; hence, any international law rules applied by the tribunal would be confined to expropriation. ${ }^{30}$ The tribunal held that customary international law was not 'a distinct and separate basis of potential liability in this case' (since the tribunal's jurisdiction did not extend to such legal bases); customary international law simply intertwined with expropriation law. ${ }^{31}$

Similarly, the tribunal also established that the MFN clause did not create a new legal basis coming under the tribunal's jurisdiction: 'MFN clauses are not and should not be

28 '36. Claimants further contend that the measures summarized above constitute further violations of Hungary's obligations under the BIT (as well as the provisions of the treaties with other States that are incorporated by the most-favored-nation principle of Article 3 of the BIT), including, without limitation, the obligation to (i) observe obligations attendant upon a direct or indirect expropriation of an investment; (ii) ensure and afford fair and equitable treatment to investments; (iii) avoid impairing by unreasonable or discriminatory measures the operation, management, maintenance, use, enjoyment or disposal of investments; (iv) not engage in nationality discrimination against Claimants and in favor of Hungarian nationals in the award of radio-broadcasting licenses; and (v) observe obligations entered into with regard to investments.

37. In addition, Claimants contend that Respondent's measures as described above violate their obligations under customary international law, including (i) the breach of the international minimum standard of treatment of foreign investors, and (ii) expropriation without compensation of Claimant's investments without observance of due process and payment of prompt, adequate and effective compensation equal to the fair market value of the investments.'

29 Decision on Respondent's objection under Arbitration Rule 41(5), para 67.

30 Decision on Respondent's objection under Arbitration Rule 41(5), para 70.

31 Decision on Respondent's objection under Arbitration Rule 41(5), para 72. 
interpreted or applied to create new causes of action beyond those to which consent to arbitrate has been given by the Parties'. ${ }^{32}$ The MFN clauses can be relied on only to the extent they are connected to arbitration.

74. The Tribunal is of the view that an investor may properly rely only on rights set forth in the basic treaty, meaning the BIT to which the investor's home state and the host state of the investment are directly parties, but not more than that. The question should be whether the rights and benefits sought by virtue of the MFN clause are included within the arbitrable scope of the basic treaty. In the instant case, the arbitrable scope of the basic treaty is expropriation, including fact and law questions related thereto. In that light, Claimants are entitled to rely on the MFN provisions of the BIT, but only insofar as such provisions relate to expropriation.

In Emmis International Holding, B.V., Emmis Radio Operating, B.V., and MEM Magyar Electronic Media Kereskedelmi és Szolgáltató Kft. v. Hungary, ${ }^{33}$ the tribunal went through a similar line of analysis, as its jurisdiction was similarly limited to expropriation claims. At the end, the tribunal declined jurisdiction as to the 'treatment' claims and rejected the expropriation claim as unfounded.

255. In the final analysis, the Tribunal is satisfied that the only proprietary right that Claimants had, capable of protection from expropriation, was the Broadcasting Right it acquired in 1997. That right was a right of limited duration. It expired on 18 November 2009. None of the ways in Claimants have sought to plead their case on the injustices that they allege were perpetrated upon them in the 2009 Tender meet the basic requirement of a property right. This being so, the Contracting States to the instruments of consent, namely the Netherlands and Switzerland BITs, have not conferred upon this Tribunal jurisdiction to determine Claimants' claims on the merits. Accordingly this Tribunal has no option but to dismiss Claimants' claims of expropriation as presently maintained in this arbitration for lack of jurisdiction.

\section{REGULATING PRICES IN THE ENERGY SECTOR}

In AES Summit Generation Limited, AES-Tisza Erömü Kft. v. Hungary, ${ }^{34}$ the claimants sued under the Energy Charter Treaty because Hungary, after abolishing regulated prices as of 1 January 2004, reintroduced them in 2006 and 2007. AES Summit, seated in the UK, owned $99 \%$ of the shares in AES-Tisza, a company incorporated under the laws of Hungary. AES Summit purchased AES-Tisza (at that time Tiszai Erömü Részvénytársaság) and agreed to pursue and complete a retrofit of all four units of the power plant and also to construct a new power plant at Borsod. At the same time, Hungary was obliged to extend the long-term power purchase agreement (PPA) with AES-Tisza and to conclude one with the power plant at Borsod (since at the relevant time the Hungarian energy market was not liberalized, the state - more precisely MVM, the state-owned Hungarian Electricity

32 Decision on Respondent's objection under Arbitration Rule 41(5), para 73.

33 Award of the Tribunal (16 April 2014)

34 ICSID Case No. ARB/07/22 (June 29, 2012). It is worthy of note that this was not the first investment dispute between the claimant and Hungary. AES Summit Generation Limited sued Hungary also in 2001 in Case ARB/01/4. However, this controversy ended in a settlement. 
Company - was the only buyer of electricity from the power plant). Although the PPA did contain a pricing formula, the prices charged by AES-Tisza to MVM entailed a general outcry, resulting in regulatory intervention in the form of regulated prices.

AES Summit and AES-Tisza claimed that their investment was expropriated due to the reintroduction of the regulated prices and also raised complaints under the ECT's 'treatment' provisions, such as fair and equitable treatment, prohibition of discrimination.

The claim as to expropriation was summarily rejected. The tribunal grasped the investment as one unit and refused to treat each element of the investment as an independently protectable investment. As a corollary, it held that Hungary did not take control over the investment and though the regulated prices decreased profitability they did not deprive the investment of its value.

14.3.1 It is evident that many state's acts or measures can affect investments and a modification to an existing law or regulation is probably one of the most common of such acts or measures. Nevertheless, a state's act that has a negative effect on an investment cannot automatically be considered an expropriation. For an expropriation to occur, it is necessary for the investor to be deprived, in whole or significant part, of the property or effective control of its investment: or for its investment to be deprived, in whole or significant part, of its value.

14.3.2 But, in this case, the amendment of the 2001 Electricity Act and the issuance of the Price Decrees did not interfere with the ownership or use of Claimants' property. Claimants retained at all times the control of the AES Tisza II plant, thus there was no deprivation of Claimants' ownership or control of their investment.

14.3.3 Moreover, Claimants continued to receive substantial revenues from their investments during 2006 and 2007, which proves that the value of their investment was not substantially diminished and that they were not deprived of the whole or a significant part of the value of their investments.

14.3.4 In these circumstances, the Tribunal concludes that the effects of the reintroduction of the Price Decrees do not amount to an expropriation of Claimants' investment(s).

The tribunal also rejected the claimants' arguments as to fair and equitable treatment, unreasonableness and discrimination.

First, the claimants complained that Hungary frustrated their legitimate expectations through reintroducing regulated prices and thus failed to provide fair and equitable treatment. The tribunal established that 'legitimate expectations can only be created at the moment of the investment', ${ }^{35}$ though it admitted that it is uncertain whether this covers the time when the investment was decided or when it was made or both. ${ }^{36}$ In this case, the investment could be regarded as having been decided and made in 1996, when AES Summit took over AES-Tisza and/or in 2001, when AES Tisza was retrofitting the Tisza II power station. ${ }^{37}$ The tribunal found that at the time of the take-over AES Summit could have no legitimate expectations as to the fact, motivation and methodology of the regulation or nonregulation of prices, since both the privatization materials and the relevant investment

35 Award (23 September 2010), para 9.3.8.

36 Para 9.3.12.

37 Para 9.3.12. 
agreements 'were explicit that Hungary would continue to set maximum administrative prices for electricity sales indefinitely into the future'. ${ }^{38}$ As far as the investments made as from 2001 are concerned, the tribunal concluded that 'Hungary made no representations/ gave no assurances of a nature that go to the heart of claimants' complaint - i.e., that following the termination of price administration on 31 December 2003, regulated pricing would not again be introduced'. ${ }^{39}$ It is noteworthy that Hungary, as the single buyer of electricity at that time, regulated the contractual relationship between itself and AES-Tisza through a legislative act (decree). Albeit Hungary did not promise that prices would not be regulated, it could have been argued that the investor when concluding a private contract with a Hungarian public enterprise (MVM), which was the only potential buyer of electricity, could have legitimately expected Hungary not to interfere with this private contract through legislative means, except there was an indication to the contrary. However, the tribunal came to the opposite conclusion: if there was no specific promise not to regulate prices, the investor could not legitimately expect Hungary not to do so. Thus, the tribunal established that the claimants' legitimate expectations were not frustrated. ${ }^{40}$ Likewise, the tribunal rejected the claims relating to the stable legal and business framework. ${ }^{41}$ As to due process, arbitrariness and transparency, the tribunal established that not all imperfections amount to a failure to provide fair and equitable treatment. 'The standard is not one of perfection. It is only when a state's acts or procedural omissions are, on the facts and in the context before the adjudicator, manifestly unfair or unreasonable' ${ }^{42}$ The tribunal concluded that Hungary's 'process of introducing the Price Decrees, while sub-optimal, did not fall outside the acceptable range of legislative and regulatory behavior'. ${ }^{43}$

Second, the tribunal also dismissed the claim that Hungary impaired the investment by unreasonable and discriminatory measures, using a fairly deferential standard. It inquired separately whether a rational policy (that is, public policy end) existed and whether Hungary's conduct could be considered reasonable in relation to that policy. ${ }^{44}$

As to the definition of the public policy, the tribunal afforded Hungary a very wide margin of appreciation: '[a] rational policy is taken by a state following a logical (good sense) explanation and with the aim of addressing a public interest matter'. ${ }^{45}$ From the three reasons listed by Hungary, the tribunal rejected the first two but accepted the third one.

Hungary alleged that it was concerned that generators would not agree to any reductions in electricity capacity in their contracts with the Hungarian national electricity enterprise. The tribunal found that states cannot use legislative power to compel private parties to give up their valid contractual rights.

10.3.12 As to this point, the Tribunal finds that it cannot be considered a reasonable measure for a state to use its governmental powers to force a private party to change or give up its contractual rights. If the state has the conviction that its contractual obligations to its investors should no longer be observed (even if it is a commercial

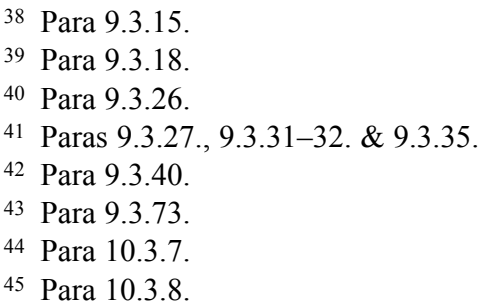


contract, which is the case), the state would have to end such contracts and assume the contractual consequences of such early termination.

Furthermore, the tribunal also rejected Hungary's argument that regulatory intervention was motivated by EU state aid concerns: the tribunal noted that 'as long as the Commission's state aid decision was not issued, Hungary had no legal obligation to act in accordance with what it believed could be the result of the decision and to start a limitation of potential state aid' ${ }^{46}$ As to this point, it is to be noted that Hungary's obligation as a Member State to refrain from providing illegal state aid stems directly from EU law; that is, this is an obligation that stands by virtue of the law and not as a consequence of the Commission's decision; the latter only pronounces an existing obligation. Therefor it was found unreasonable to expect a Member State to await the Commission's final decision, if the concerns under EU state aid law were genuine.

The tribunal endorsed Hungary's third argument and by this it looks as if it sanctioned something it had rejected when dismissing the first public interest explanation. Hungary's third argument was that power plants (including AES-Tisza) were afforded excessively high profits under the PPAs concluded with MVM and this resulted in higher burdens for consumers. ${ }^{47}$ The tribunal considered this goal to be reasonable and legitimate.

10.3.34 Having concluded that Hungary was principally motivated by the politics surrounding so-called luxury profits, the Tribunal nevertheless is of the view that it is a perfectly valid and rational policy objective for a government to address luxury profits. And while such price regimes may not be seen as desirable in certain quarters, this does not mean that such a policy is irrational. One need only recall recent wide-spread concerns about the profitability level of banks to understand that so-called excessive profits may well give rise to legitimate reasons for governments to regulate or reregulate.

While it is true that the price-regulation governed all transactions, it cannot be disregarded that at the relevant time MVM, which was controlled by the state and, as such, acted as the long-arm of the state, was in a dominant position regarding the purchasing of electricity, buying the vast majority of the electricity produced in Hungary.

The tribunal also established that Hungary's acts could be considered reasonable in relation to that policy. ${ }^{48}$ The price regulation was reasonable, proportionate and consistent with the public policy pursued, ${ }^{49}$ it ensured the claimants a reasonable return ${ }^{50}$ and was not discriminatory, the price established for each power plant was established on the basis of the same methodology, ${ }^{51}$ and it breached neither the requirement of national treatment, ${ }^{52}$ nor the principle of most favored nation treatment. ${ }^{53}$

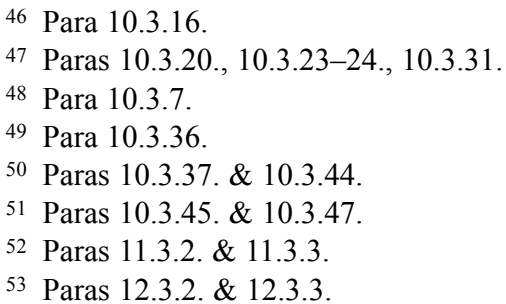




\section{TERMINATION OF LONG-TERM ELECTRICITY POWER PURCHASE AGREEMENTS COMPELLED BY EU STATE AID LAW}

Interesting cases emerged from Hungary's termination of the long-term electricity power purchase agreements (PPAs) that raised novel questions of interpretation. Hungary (as the facts of AES Summit demonstrate) privatized its power plants in the mid '90s. The main reason behind was that the infrastructure and facilities were outdated and needed retrofitting for which Hungary wanted to attract foreign investors. According to the privatization agreements, various investors purchased the power plants and entered into contractual obligations to retrofit; however, at that time, the Hungarian electricity market was not liberalized, and MVM was an unavoidable contracting partner for the power plants, hence the investors needed a guarantee that they would recover on their investments. For this reason, in parallel to the privatization contracts, they also entered into long-term power purchase agreements (PPAs) with MVM that the latter would purchase, the electricity they produced at a given price. However, after Hungary's accession to the EU, the European Commission established that these PPAs contained veiled state aid, as the price paid by MVM exceeded the market price.

Two investment disputes were launched after the termination of the PPAs. While the ICSID tribunal decided for Hungary in Electrabel S.A. v. Republic of Hungary, ${ }^{54}$ in EDF International S.A. v. Republic of Hungary ${ }^{55}$ the claimant (in an ad-hoc arbitration proceeding conducted under the UNCITRAL rules, in which the award is not publicly available) was awarded $€ 107$ million. ${ }^{56}$

In Electrabel S.A. v. Republic of Hungary, the claimant sued Hungary, first, because, in line with the Commission's state aid decision, it terminated, through a legislative act, the PPAs with MVM and, second, because Hungary reintroduced price-regulation. As noted above, Hungary privatized its power plants in the ' $90 \mathrm{~s}$. The claimant purchased the majority of the shares of Dunamenti power plant and invested considerable funds into it for the purpose of retrofitting. Dunamenti had a PPA with MVM. Such contracts were common at that time and meant to back the privatization of the power plants: these facilities needed significant retrofitting and the long-term contracts were meant, in economic terms, to guarantee the investors that they would be able to sell the electricity they produce.

The expropriation claim raised two issues. First of all, the tribunal had to decide whether Hungary, in principle, could be held liable for terminating the PPAs taking into account that it had an obligation, emerging from EU law, to do so. It could have been argued that since EU law has supremacy over Member State laws, it was not Hungary's decision to terminate the contracts. On the other hand, it could have been also plausibly argued that both conflicting duties (expropriation with just compensation and prohibition of anti-competitive state aid) had been freely assumed by Hungary and it should have been aware of its obligations under the ECT when joining the EU and Hungary should have requested a derogation. Second, it was questionable whether the termination of the PPA could be regarded as expropriation (in a wider sense) at all. The claimant was certainly deprived of its right to sell the power at a relatively high price as guaranteed in the contract.

54 ICSID Case No. Arb/07/19.

55 The award was rendered on December 4, 2014. The tribunal consisted of Karl-Heinz Böckstiegel (chair), Pierre-Marie Dupuy and Albert Jan van der Berg.

56 http://globalarbitrationreview.com/news/article/33251/edf-wins-claim-against-hungary/ accessed 20 October 2017. 
If this right is regarded as an investment, the occurrence of expropriation is out of question. However, if the investment is described as a bundle of rights, this also implies that the nullification of one element does not necessarily mean that the claimant's investment was deprived of its value.

The tribunal grasped the relationship between the ECT and EU law on an abstract level. The tribunal did not succeed in cutting (or rather did not have to cut) the Gordian knot entailed by the sui generis nature of EU law. On the one hand, the tribunal established that there is no reason to treat EU law differently from 'ordinary' international law: 'there is no fundamental difference in nature between international law and EU law that could justify treating EU law, unlike other international rules, differently in an international arbitration requiring the application of relevant rules and principles of international law'. ${ }^{57}$ On the other hand, the tribunal established that EU law is to be treated as national law: "when it is not applied as international rules under the ECT, EU law must in any event be considered as part of the Respondent's national legal order, i.e. to be treated as a 'fact' before this international tribunal'. ${ }^{58}$

As to the relationship between the ECT and EU law, though the tribunal disagreed with the proposition that 'there is a general principle of international law compelling the harmonious interpretation of different treaties', ${ }^{59}$ it established that the relationship between the ECT and EU law is somewhat special, hence 'the ECT should be interpreted, if possible, in harmony with EU law'. ${ }^{60}$ First, the EU and its Member States were closely involved in the adoption of the ECT and since according to Article 207(3) TFEU '(t)he Council and the Commission shall be responsible for ensuring that the agreements negotiated are compatible with internal Union policies and rules', ${ }^{61}$ it can be assumed that the EU did not envisage entering into obligations that run counter to EU law; 'the ECT's conclusion by the EU and its Member States at that time (...) should be presumed, in the absence of clear language or cogent evidence otherwise, to have been made in conformity with EU law'. ${ }^{62}$ Second, the ECT and the EU have similar objectives: the ECT 'is an instrument clearly intended to combat anti-competitive conduct, which is the same objective as the European Union's objective in combating unlawful State aid'. ${ }^{63}$ Third, the tribunal also established ${ }^{64}$ that the ECT implicitly recognized that Commission decisions are binding on all Member States. ${ }^{65}$

The tribunal came to the conclusion that 'there can be no practical contradiction between the ECT and EU law in regard to the Final Decision' - 'the ECT does not protect

57 Award of the Tribunal (25 November 2015), para 4.126.

58 Para 4.127.

59 Para 4.130.

60 Para 4.130.

${ }^{61}$ Para 4.135-36.

${ }^{62}$ Para 4.134. In this regard, the tribunal referred to Article 32 of the Vienna Convention on the Law of Treaties, which provides that the circumstances of the treaty's conclusion may be used as a supplementary means of interpretation.

63 Para 4.133. See also paras 4.137. \& 4.141.

${ }^{64}$ Para 4.142.

${ }^{65}$ See Article 1(3) ECT: “A "Regional Economic Integration Organization" means an organization constituted by states to which they have transferred competence over certain matters a number of which are governed by this Treaty, including the authority to take decisions binding on them in respect of those matters.' 
the Claimant, as against the Respondent, from the enforcement by the Respondent of a binding decision of the European Commission under EU law' ${ }^{66}$ However, the supremacy of EU law provides immunity only to the Member State, which acts under the authority of the Commission (state aid) decision, ${ }^{67}$ the EU is not shielded from liability under the ECT. 'This analysis leaves open the responsibility of the European Union under the ECT for decisions of the European Commission which violate the rights of investors under the ECT. ${ }^{68}$ In this sense the decision suggests that the claimant sued the wrong defendant.

Nonetheless, the tribunal also established that the immunity Hungary enjoys as a result of the Commission's state aid decision ranges only to the point where it has no autonomy of action. Once a particular detail is left to the discretion of the Member State or is not mandated by the Commission decision, that Member State's individual liability emerges and the tribunal will scrutinize this under the applicable standards.

6.72 Where Hungary is required to act in compliance with a legally binding decision of an EU institution, recognized as such under the ECT, it cannot (by itself) entail international responsibility for Hungary. Under international law, Hungary can be responsible only for its own wrongful acts. The Tribunal considers that it would be absurd if Hungary could be liable under the ECT for doing precisely that which it was ordered to do by a supranational authority whose decisions the ECT itself recognises as legally binding on Hungary.

$(\ldots)$

6.76 For these reasons, the Tribunal decides that if and to the extent that the European Commission's Final Decision required Hungary, under EU law, prematurely to terminate Dunamenti's PPA, that act by the Commission cannot give rise to liability for Hungary under the ECT's FET standard. The Tribunal next considers what the Final Decision did require of Hungary under EU law.

Hungary created a scheme for establishing the net stranded costs and for compensating the power plants for these (in case these had not been recovered). The tribunal found that Hungary's own acts were in line with the applicable standards; however, since the last stage of this scheme was to be carried out at the time of the award, the tribunal reserved the right to decide on this in another award. ${ }^{69}$

It is to be noted that should the tribunal have decided otherwise, that would have entailed a vicious circle. As the Commission made it clear in its submissions: in the same way as the PPAs contained a veiled state aid, any money paid in exchange for (that is, substituting) this 'right to sell' must equally qualify as a state aid; in other words, if

66 Para 4.169.

67 4.191. In summary, from whatever perspective the relationship between the ECT and EU law is examined, the Tribunal concludes that EU law would prevail over the ECT in case of any material inconsistency. That conclusion depends, however, upon the existence of a material inconsistency; and the Tribunal has concluded that none exists for the purpose of deciding the Parties' dispute in this arbitration.

4.196. As regards the Parties' arbitration agreement and the merits of their dispute, the Tribunal concludes that there is in this case no material inconsistency between the ECT and EU law.

68 Para 4.170.

69 Paras $6.108-09$ \& 6.118. 
compensation were awarded and paid, the Commission would have no choice but to enjoin Hungary to recover this from the claimant.

4.110. According to the European Commission, the pre-eminence of EU law has important consequences for the implementation of any award which contradicts EU law on State aid. According to the Commission, an award that substituted compensation for State aid unlawful under EU law would not be enforceable because it would be equivalent to a judgment of a national court of an EU Member State made in contradiction with EU law:

'EU Member States are obliged under EC law to carry out Commission State aid decisions. If the Tribunal rendered an award that is contrary to obligations binding on Hungary as an EU Member State, such award could not be implemented in Hungary by virtue of the supremacy of EC law'.

As to expropriation, the tribunal grasped the claimant's investment as its interests in Dunamenti; that is, it conceived the investment in wider sense and did not regard the right to sell electricity (the PPA) as an investment. As a consequence of this, the claimant should have demonstrated that the termination of the PPA deprived its interests in Dunamenti power plant of their value.

6.53 As regards indirect expropriation, the Tribunal considers that the wording of Article 13(1) ECT requires Electrabel to establish that the effect of the PPA's termination by Hungary was materially the same as if its investment in Dunamenti had been nationalised or directly expropriated by Hungary. In other words, Electrabel must prove, on the facts of this case, that its investment lost all significant economic value with the PPA's early termination. (...) In terminating the PPA by legislation, the Tribunal notes that Hungary has not deprived Dunamenti of the use of its power plant, equipment or other real property; and Dunamenti's business, taken as a whole, was not rendered financially worthless by the PPA's early termination but has continued thereafter as an economic concern competing in Hungary's electricity market, with its plant still operational and operated by Dunamenti.

(...)

6.57 (...) If it were possible so easily to parse an investment into several constituent parts each forming a separate investment (as Electrabel here contends), it would render meaningless that tribunal's approach to indirect expropriation based on 'radical deprivation' and 'deprivation of any real substance' as being similar in effect to a direct expropriation or nationalisation. It would also mean, absurdly, that an investor could always meet the test for indirect expropriation by slicing its investment as finely as the particular circumstances required, without that investment as a whole ever meeting that same test. (...)

6.58 In this Tribunal's view, it is clear that both in applying the wording of Article 13(1) ECT and under international law, the test for expropriation is applied to the relevant investment as a whole, even if different parts may separately qualify as investments for jurisdictional purposes. Here the investment held by Electrabel as a whole was its aggregate collection of interests in Dunamenti; it was thus one integral investment; and in the context of expropriation it was not a series of separate, individual investments with Dunamenti's PPA as an autonomous investment set apart from Electrabel's other interests in Dunamenti. In the Tribunal's view, Electrabel's 
investment was manifestly not confined to the PPA; and the PPA formed an intrinsic and inseparable part of Electrabel's investment as a whole.

The claimant also claimed that Hungary's introduction of price regulation went counter to the requirement of fair and equitable treatment. The tribunal considered that the claimant could have no legitimate expectation that Hungary would not introduce regulated prices, ${ }^{70}$ simply because 'Electrabel's investment was made on the basis of regulated pricing'; ${ }^{71}$ so the relevant question was not whether Hungary was entitled to reintroduce regulated prices but 'whether in so doing, Hungary acted reasonably, in good faith and without improper motives towards Dunamenti in compliance with Article 10(1) ECT' ${ }^{72}$

The tribunal rejected the claimant's allegations that the introduction of price regulation was backed by populist politics - according to the tribunal political rhetoric is part of the democratic process and does not overshadow rational policy considerations.

8.23 There is no doubt that by late 2005 and early 2006 there was political and public controversy in Hungary over the perceived high level of profits made by Hungarian Generators, including Dunamenti. However, politics is what democratic governments necessarily address; and it is not, ipso facto, evidence of irrational or arbitrary conduct for a government to take into account political or even populist controversies in a democracy subject to the rule of law. Moreover, the Hungarian Government did not itself resort to populist language directed at Dunamenti. In brief, the Tribunal considers that Electrabel's criticism of Hungary's political motives is factually mistaken, particularly in alleging that Hungary's conduct towards the Generators (especially Dunamenti) was induced solely by malign populist pressures, now falsely camouflaged with other ostensibly more rational factors for the purpose of Hungary's defence in these arbitration proceedings.

Hungary's concerns that the price embedded in the PPAs could fall foul of EU state aid law were susceptible of legitimizing the introduction of price regulation, albeit at the relevant time the Commission had adopted no decision on this.

8.26 In the Tribunal's view, it was therefore not irrational for Hungary temporarily to take into account this standstill obligation in promulgating the regulatory measures (by operation of law) of which Electrabel now complains. The Tribunal acknowledges that, at this particular time, Hungary could not foresee the actual result of the European Commission's investigations (almost two years' later). Hungary's conduct was prudent; and in the circumstances, it was certainly not rendered irrational by the Commission's Final Decision. It is also significant that the European Commission's Submission confirms that Hungary's price regulation was made to bring its energy sector into line with the requirements of EU law, in particular EU law on State aid (paragraph 17).

8.27 For the purpose of price regulation by operation of law, the Tribunal therefore accepts that, at this time, it was not unreasonable for Hungary to understand (as in fact

\footnotetext{
70 Para 8.18.

71 Para 8.19.

72 Para 8.22.
} 
it did) and to act upon the European Commission's communications as a warning that Hungary should seek to discontinue unlawful State aid received by Generators under the PPAs, including Dunamenti.'

Interestingly, this argument is not reconcilable with the award in AES Summit Generation Limited, AES-Tisza Erömü Kft. v. Hungary, ${ }^{73}$ where the tribunal found the fear from the European Commission's procedure and the risk of illegal state aid did not qualify as a legitimate public interest in the eyes of the tribunal, noting that 'as long as the Commission's state aid decision was not issued, Hungary had no legal obligation to act in accordance with what it believed could be the result of the decision and to start a limitation of potential state aid'. ${ }^{74}$

\section{CIVIL-LAW CONTROVERSY AND INVESTMENT DISPUTE}

In Vigotop Limited $v$ Hungary, ${ }^{75}$ the claimant envisaged constructing a casino (King City) and for this purpose concluded a concession agreement with Hungary. The annex of that agreement listed numerous locations and provided that the casino had to be constructed on any of those. Before the publication of the call for tenders for the conclusion of a concession agreement (which occurred on 10 February 2009), ${ }^{76}$ the claimant concluded a land swap agreement (on 30 July 2008) to acquire title over a plot near the city of Sukoro (one of the plots listed in the tender). On 14 August 2009, KC Bidding (a project company owned by the claimant) was announced as the winner of the tender ${ }^{77}$ and on 9 October 2009 the concession agreement was signed. However, two hours after the conclusion of the concession agreement, the Hungarian Ministry of Finance issued a press release stating that negotiations would be started as to the Sukoró land swap 'with the aim of restoration of the original - pre-land-swap condition' ${ }^{78}$ At the end of the day, the Hungarian court established that the acquisition of the Sukoro site was illegal and ordered the restoration of the initial status.

Under Hungarian law, state-owned arable land can be alienated only through a public tender; however, this requirement does not apply if the State wishes to acquire a land 'for the purposes of public utility infrastructure projects or for some other reason of public interest'; in this case a land swap is permitted. The investor, Mr. Blum, the owner the claimant entities, in order to secure a proper site for the casino for the purposes of the concession agreement, wanted to acquire the Sukoró site. He had three plots in a nearby city, Albertirsa. It was established that the by-pass section of motorway 'M4' (which was under construction at that time) touched two of these real estates. The MNV (Hungarian National Asset Management Company) concluded a land swap contract with Mr. Blum, where the latter transferred title over these three real estates and paid a certain amount of money to the MNV, while the MNV transferred title over the Sukoró plot. However, the Hungarian Supreme Court (Kúria) pronounced, in November 2012, the land swap agreement as null and void, finding that it had violated Section 13(4) of Act CXVI of 2001 on National

73 ICSID Case No. ARB/07/22.

74 Para 10.3.16.

75 ICSID Case No. ARB/11/22.

76 Award (1 October 2014), para 123.

77 Para 127.

78 Para 154. 
Land Fund: it was not justified neither by 'the purposes of public utility infrastructure projects' nor by 'some other reason of public interest'. The future construction of motorway M4 concerned only two of the three plots, and even as to the latter, the effect of the motorway was minimal. ${ }^{79}$

Although the claimant could have chosen any of the plots listed in the concession agreement's annex (which listed 133 locations), ${ }^{80}$ it insisted on constructing the casino on the Sukoró site. Since the concessionaire failed to secure a plot in one of the 133 locations listed in the concession agreement's annex, the Hungarian state terminated the concession agreement and demanded payment of the penalty stipulated. The legal dispute concerning the termination was pending at the time of the ICSID proceeding.

The pivotal legal question of the case was whether Hungary's termination of the concession agreement qualified as a state measure or could not be regarded as an expropriatory act by its nature; notably, Hungary's termination of the concession agreement was a private act (acta jure gestionis) and arguably the legal dispute between the parties did not qualify as a controversy between an investor and a sovereign but as a purely contractual dispute.

312. The Tribunal observes that the analysis whether certain conduct constitutes an expropriatory act cannot be carried out in an abstract manner, but rather must be based on the specific facts of the case. It has to be noted that the Concession Contract was not terminated by way of legislative act or executive decree, but rather by Respondent's exercise of negotiated contractual termination rights, on the grounds that Claimant allegedly failed to comply with its contractual obligations. In the Termination Letter, Respondent did not purport to invoke any of its sovereign prerogatives. On its face, Respondent's termination notice would therefore appear to be the act of an ordinary contracting party rather than the act of a sovereign State.

The tribunal defined the purview of 'expropriatory act' widely and went into the intricacies of the commercial dispute, establishing the following three-prong test. First, it has to be analyzed whether Hungary had public policy reasons to terminate the concession agreement - or the decision to terminate the agreement was based on purely contractual considerations. Second, in case of public policy reasons, it has to be ascertained whether the termination has a contractual ground. Third, in case of a contractual ground, it has to be examined whether the termination was legitimate, that is, whether Hungary acted in good faith.

328. The Tribunal will therefore begin its analysis by focusing on the key question: whether - to put it in the words of Prof. Schrijver - Respondent "stepped out of the contractual shoes" and, in fact, acted in its sovereign capacity when it terminated the Concession Contract. Accordingly, the Tribunal will first examine whether, as alleged by Claimant, Respondent had "a hidden political agenda", which was the true reason for its termination of the Concession Contract, meaning that Respondent in fact took this decision in order to give effect to a change in government policy, and thus in its sovereign capacity. If this were not the case, this would exclude the finding of an

79 Para 198.

80 Para 145. 
expropriation regardless of whether Respondent acted in accordance with the terms of the Concession Contract and Hungarian law. However, even if the Tribunal were to conclude that Respondent indeed had public policy reasons to terminate the Concession Contract, this would not necessarily in itself lead to a finding that the termination amounted to an expropriation because Respondent could at the same time have had contractual grounds for terminating the Concession Contract.

329. In the latter case, the Tribunal would therefore have to continue its analysis by examining, as a second step, whether contractual grounds for terminating the Concession Contract in fact existed. In the Tribunal's view, a finding that none of the contractual grounds invoked by Respondent were sufficiently well-founded, while not being dispositive of the expropriation question in itself, could indicate that they were merely a pretext designed to conceal a purely expropriatory measure. If, on the other hand, the Tribunal were to reach the contrary conclusion, i.e., that Respondent had contractual termination grounds in addition to its public policy reasons, this would require a further analysis.

330. In the event of such a parallel cause (public policy reasons and contractual grounds), the Tribunal would thus have to examine, as a third and final step, whether the contractual termination was legitimate, i.e., consistent with the good faith principle. To be specific, the Tribunal would have to determine whether the termination constituted an abuse of the contractual right in order to avoid liability to compensate, that is, whether it involved a "fictitious" or "malicious" exercise of the right to terminate.

331. If the Tribunal were ultimately to conclude that it was indeed legitimate for Respondent to invoke its contractual grounds for terminating the Concession Contract, this would exclude a finding of an expropriation, despite the parallel existence of public policy reasons. The issues for determining an expropriation in the context of a contract termination are (i) whether the contract is terminated by the contractual procedure rather than a legislative act or executive decree, and (ii) whether there exists a legitimate contractual basis for termination, i.e., (a) the contract or the governing law provides the ground for termination, (b) the evidence substantiates a factual basis for invoking the contractual ground, and (c) the State acts in good faith, not abusing its right by a fictitious or malicious exercise of it.

In sum, the tribunal held that the termination of the concession agreement had to be examined, independent of any national court decision, since it was, in part, based on public policy reasons (new environmental and touristic public policies new environmental and touristic public policies); furthermore, 'concerns about corruption in the land swap, although such concerns ultimately proved unfounded, may also have played a role in the Government's decision to terminate the Concession Contract'. However, Hungary had a solid contractual ground to terminate the concession agreement and exercised its right in good faith: the claimant failed to secure a suitable plot for the purpose of the concession agreement. '[T]he Government included in the Contract a list of potential sites (still including Sukoró as one of them) at which the Project could be located. Claimant thus had ample options but failed to secure any site other than Sukoró, thereby assuming the risk that it would not have a valid title'. ${ }^{81}$ 


\section{INVESTMENT CLAIMS EMERGING FROM A JUDICIAL ERROR}

The recent decision in Dan Cake (Portugal) S.A. v. Hungary ${ }^{82}$ is one of the very rare cases where a state was condemned for a judicial error. The Hungarian bankruptcy court opened a bankruptcy proceeding against the claimant's subsidiary in Hungary (Danesita). With the help of its parent company, Danesita reached agreements with various creditors and requested the Hungarian court to convene a 'composition hearing' with the aim of entering into a compromise with the creditors. However, the court rejected the request for a hearing and, instead, ordered Danesita to satisfy numerous conditions; 'it [also] insisted that the liquidator was obliged to proceed with the sale of its assets within 120 days from the publication of the liquidation proceedings'. ${ }^{83}$ Shortly thereafter, the auction sale of Danesita's factory was announced by the liquidator.

The tribunal established that the rejection to convene a hearing amounted to the 'flagrant violation' of Hungarian law; ${ }^{84}$ and although '[i]t is impossible (...) to determine whether a composition agreement would have been reached if a composition hearing had been convened', this deprived the claimant of the fair and equitable treatment (in the form of denial of justice): ${ }^{85}$ As the tribunal found: 'one thing is certain: whatever was the chance of a successful composition hearing, it was destroyed by the Bankruptcy Court's decision to refuse to convene a hearing within 60 days, as required by the law' ${ }^{86}$

The Decision on Jurisdiction and Liability was rendered on 24 August 2015. The case is still pending as to the quantum of damages.

\section{CLOSING WORDS}

The Hungarian experiences with (ICSID) investor-state arbitration have been rather diverse, ranging from unlawful expropriation to judicial errors. The bulk of the Hungarian cases have not centered around expropriation but 'treatment' claims (such as fair and equitable treatment): price regulation, public tenders (frequencies), contractual disputes related to concession agreement and improper application of national law by the national judiciary. Even though tribunals appeared to be highly deferential and Hungary won the vast majority of the disputes, these cases show the far-reaching and ever-widening sphere of operation of international investment arbitration.

\section{LITERATURE}

Nagy, Csongor István, 'Central European Perspectives on Investor-State Arbitration: Practical Experiences and Theoretical Concerns' in de Mestral, Armand (ed), Investor State Arbitration between Developed Democracies (McGill-Queen's University Press 2017) 309-32.

82 ICSID Case No. ARB/12/9.

83 Decision on Jurisdiction and Liability (24 August 2015), para 54.

84 'It also results from the above analysis of the decision that it was rendered in flagrant violation of the Bankruptcy Act and that it purported to condition the mandatory convening of the hearing upon several requirements, all of which were unnecessary; two of which were in direct violation of Dan Cake's creditor rights; and at least one of which was impossible to satisfy within a reasonable time.' Para 142.

85 Para 146.

86 Para 142. 
Nagy, Csongor István, 'The Metamorphoses of Universal Service in the European Telecommunications and Energy Sector: A Trans-Sectoral Perspective' (2013) 14(9) German Law Journal 1731-56.

Víg, Zoltán and Doklestic, Slobodan, Requirements of Lawful Taking of Foreign Property in International Law (Pólay Elemér Alapítvány 2015).

Víg, Zoltán and Gajinov, Tamara, 'The development of compensation theories in international expropriation law’ (2016) 57(4) Hungarian Journal of Legal Studies 447-61. 